\title{
Некоторые вопросы деятельности уголовно-испомнтельных инспекций по испомнению наказания в виде исправительных работ
}

\author{
Л. Н. ТАРАБУЕВ \\ Вологодский институт права и экономики ФСИН России, г. Вологда, Россий- \\ ская Федерация
}

ORCID: https://orcid.org/0000-0003-3372-9810, e-mail: tarabuev@list.ru

Р е ферат

Введение: в статье на основе анализа официальных данных и результатов проведенного автором исследования обозначены основные проблемы деятельности уголовноисполнительных инспекций по привлечению осужденных к наказанию в виде исправительных работ. Цель: с учетом существующей практики исполнения наказания в виде исправительных работ сформулировать некоторые организационные и правовые предложения по обеспечению деятельности уголовно-исполнительных инспекций, направленные на повышение эффективности исполнения наказания данного вида. Методы: обобщение, сравнение, диалектико-материалистическая теория познания, анкетирование, экспертная оценка, статистический анализ, сравнительно-правовой. Результаты: выработанные предложения по изменению действующего законодательства позволят повысить эффективность деятельности уголовно-исполнительных инспекций по исполнению наказания в виде исправительных работ как реальной и востребованной альтернативы лишению свободы. Выводы: основными причинами недостаточного привлечения к труду осужденных к исправительным работам являются: отсутствие эффективной предварительной работы, позволяющей создать условия для организации труда осужденных данной категории, как со стороны инспекции, так и со стороны территориального органа ФСИН России; низкий уровень взаимодействия инспекций с муниципальными органами различного уровня и государственными органами региона, что не дает возможность привлечь осужденных к труду в полном объеме; отсутствие организационно-правового механизма стимулирования работодателей в сфере трудоустройства осужденных; непроработанность в органах государственной власти субъектов Российской Федерации вопросов о необходимости внесения соответствующих изменений в региональное законодательство для снижения налога на прибыль предприятий и организаций, которые предоставляют рабочие места осужденным к исправительным работам; отсутствие инициативы со стороны персонала инспекций в деле решения вопросов квотирования рабочих мест в учреждениях, где трудятся осужденные; недостаточное всестороннее изучение личности осужденного, склонного к совершению преступлений и иных правонарушений. Очевидна необходимость разработки механизма правового регулирования функционирования уголовно-исполнительных инспекций в сфере исполнения наказания в виде исправительных работ.

Ключевые слова: уголовно-исполнительная инспекция; исправительные работы; осужденный; привлечение к труду; квотирование; налоговые льготы; взаимодействие.

12.00.11 - Судебная деятельность, прокурорская деятельность, правозащитная и правоохранительная деятельность (юридические науки).

Для цитирования: Тарабуев Л. Н. Некоторые вопросы деятельности уголовно-исполнительных инспекций по исполнению наказания в виде исправительных работ. Пенитенциарная наука, 2021, т. 15, № 1 (53), с. 74-84. DOI 10.46741/2686-97642021-15-1-74-84.

\section{Some Issues in the Work of Probation Inspectorates Related to the Execution of Sentences in the Form of Correctional Labor}

\author{
LEONID N. TARABUEV \\ Vologda Institute of Law and Economics of FSIN Russia, Vologda, Russian \\ Federation
}


ORCID: https://orcid.org/0000-0003-3372-9810, e-mail: tarabuev@list.ru

A bstract. Introduction: we usethe analysis of official data and the results of our own research to identifymajor issues in the work ofprobation inspectorates aimed at executing penalties in the form of correctional labor. Aim: taking into account current practice of execution of punishment in the form of correctional labor, we formulate some organizational and legal proposals for supporting the activities of probation inspetorates, aimed at improving the effectiveness of execution of this type of punishment. Methods: generalization, comparison, dialectical-materialistic theory of knowledge, questionnaire survey, expert assessment, statistical analysis, comparative-legal method. Results: our proposals for changing the current legislation will help to enhance the performance of probation inspectoratesin their work related to the execution of sentences in the form of correctional labor as a real and in-demand alternative to incarceration. Conclusions: main reasons for insufficient labor involvement of convicts sentenced to correctional worksare as follows: probation inspectorates and territorial bodies of the Federal Penitentiary Service of Russia do not conduct effective preliminary work that wouldhelp to create favorableworkingconditions for the convicts in this category; cooperation of probation inspectorates with municipal authorities at various levels and with regional state authorities is at a low level; as a result, convicts cannot be brought to work in full; there is no legal mechanism to encourage employers to provide jobs to convicts; regional state authorities have yet to introduce appropriate changes to regional legislation so as to reduce the tax on profits of enterprises and organizations that provide jobs for those sentenced to correctional labor; probation inspectorates staff lack initiative with regard to employment quotas in institutions where prisoners work; the personality of a convicted person who is prone to committing crimes and other offenses has not been studied thoroughly. It is obvious that there is a need to develop a mechanism for legal regulation of the functioning of probation inspectorates in the field of execution of sentences in the form of correctional labor.

Keywords: probation inspectorate; correctional labor; convict; engagement in labor; quotas; tax benefits; interaction.

12.00.11 - Judicial activities, prosecutor's activities, human rights and law enforcement activities.

For c it a ti o n: Tarabuev L.N. Some issues in the work of probation inspectorates related to the execution of sentences in the form of correctional labor. Penitentiary Science, 2021, vol. 15, no. 1 (53), pp. 74-84. DOI 10.46741/2686-9764-2021-15-1-74-84.

\section{Введение}

Актуальность темы исследования обусловлена необходимостью приведения функционирования уголовно-исполнительных инспекций (далее - УИИ) в соответствие с мировыми и европейскими стандартами организационно-правового обеспечения законности при исполнении наказаний. В связи с этим и в целях оптимизации системы уголовных наказаний, а также с учетом общественной опасности преступлений и личности осужденного, нейтрализации отрицательных последствий лишения свободы расширяется сфера применения наказаний, альтернативных лишению свободы.

Одним из видов наказаний, не связанныхс изоляцией осужденного от общества, являются исправительные работы. Их примене-

\footnotetext{
${ }^{1}$ Статья написана на основе материалов диссертации автора на соискание ученой степени кандидата юридических наук «Организация и правовые основы деятельности уголовно-исполнительных инспекций по исполнению наказания в виде исправительных работ», публикуется впервые.
}

ние направлено на снижение общего количества лиц, содержащихся в исправительных учреждениях, и дает гражданам, впервые совершившим преступления, возможность исправиться без лишения свободы. По мнению А. А. Устинова, к очевидным достоинствам исследуемого наказания относятся: возможность сохранить или усовершенствовать трудовые навыки осужденного; экономическая выгода в виде финансовых отчислений в бюджет; привитие и поддержание трудовой дисциплины; сохранение социальных связей осужденного, возможность поддерживать контакты с родственниками, вступать в брак, воспитывать детей, заниматься другой социализирующей деятельностью; отсутствие негативного влияния осужденных - носителей криминальной субкультуры, гораздо меньшая степень социальной стигматизации осужденного, чем при лишении свободы [19, с. 338].

Реализация такого альтернативного вида наказания, как исправительные работы, яв- 
ляется перспективным направлением уголовно-исполнительной политики, гармонично вписывающимся в ее гуманистические рамки [14, с. 121].

Как показывает практика, данный вид наказания - один из наиболее часто применяемых в Российской Федерации. Об этом свидетельствуют данные судебной статистики: в 2010 г. осуждены к исправительным работам 41282 чел., в 2011 г. - 40 037, в 2012 г. 70 400, в 2013 г. - 75 902, в 2014 г. - 75 120, в 2015 г. - 60 794, в 2016 г. - 51 689, в 2017 г. 54 753, в 2018 г. - 54 747, в 2019 г. - 50020. Другими наиболее применяемыми наказаниями, например в 2019 г., стали: лишение свободы - 175 122, обязательные работы 99 652, штраф - 74 752, ограничение свободы - 20420 [3]. Таким образом, достаточно продолжительный период времени прослеживается стабильно высокий показатель применяемости исправительных работ, а по итогам 2019 г. они заняли четвертое место среди всех уголовных наказаний.

Значительный рост состоящих на учете в уголовно-исполнительных инспекциях лиц, осужденных к исправительным работам, произошел после принятия Федерального закона от 07.12.2011 № 420-ФЗ «О внесении изменений в Уголовный кодекс Российской Федерации и отдельные законодательные акты Российской Федерации» [8], изменившего содержание рассматриваемого наказания. Оно стало назначаться как лицам, которые имели основное место работы до осуждения, так и не имевшим такового.

На внесенные изменения суды отреагировали не в должной мере, особенно в тех случаях, когда данный вид наказания назначался лицам, не работавшим до осуждения, а также исполнение наказания предполагалось в районах, где осужденный до приговора суда не проживал. Таким образом, суды в ряде случаев назначали исправительные работы лицам, не имеющим официального места работы, либо лицам, которые длительное время не имели по разным причинам (отсутствие желания работать, алкогольная зависимость) постоянного места работы и, соответственно, источника дохода.

Официальные статистические данные Федеральной службы исполнения наказаний (далее - ФСИН России) в целом по стране демонстрируют уровень привлечения осужденных к отбыванию исправительных работ в пределах 99 \% от общего количества осужденных к ним лиц. Однако такой высокий показатель характерен не для всех инспекций территориальных органов ФСИН России. По мнению Д. В. Косолаповой, крайне слабо организовано трудоустройство осужденных к исправительным работам в республиках Адыгее, Крым, г. Севастополе, Белгородской, Тамбовской, Магаданской областях [6].

Уместно отметить и рост в последние годы показателя непривлечения осужденных в установленный законом срок к отбыванию наказания в виде исправительных работ: так, например, в 2015 г., по данным сводного отчета о работе УИИ за 2015-2019 гг., он составил 73,22, в 2016 г. - 72,93, в 2017 г. 98,26, в 2018 г. - 151,36, в 2019 г. - 236,93.

Некоторые вопросы привлечения к труду лиц, осужденных к наказанию в виде исправительных работ

Трудоустройство осужденных к исправительным работам, не имеющих основного места работы, возможно лишь на предприятиях, в учреждениях и организациях, определенных органами муниципального образования и согласованных с инспекцией, но по месту жительства осужденного. Согласно официальным данным таких вакантных мест на самих муниципальных предприятиях, в организациях и учреждениях недостаточно, поскольку происходит их поэтапное сокращение из-за реорганизации жилищно-коммунального хозяйства, а также по причине того, что эти органы обязаны изыскивать дополнительные рабочие места и для другой категории лиц - осужденных к обязательным работам. В связи с этим даже в случае нахождения работы она будет низкооплачиваемой. Отмечается, что на предприятиях иной формы собственности трудоустройство лиц рассматриваемой категории также проблематично, потому что отношения с предприятиями, учреждениями и организациями, не являющимися муниципальными, строятся на договорной основе, то есть требуется заключение соответствующего договора с руководством организации.

Таким образом, основной сложностью в деятельности УИИ по организации исполнения исследуемого наказания по-прежнему остается привлечение осужденных к труду. Это обусловлено тем, что существующие в настоящее время организационно-правовые основы деятельности УИИ по привлечению к труду лиц, осужденных к исправительным работам, вряд ли могут считаться достаточно действенными [21, с. 3]. 
Отсутствие работы, недостаток средств к существованию, невозможность исполнить наложенную судом обязанность и возместить причиненный материальный вред, потребность в перечислении алиментов и налогов - вот основные причины, приводящие к совершению новых преступлений [16, C. 437].

В период с 2014 по 2018 г. нами в рамках диссертационного исследования были проанкетированы 1172 сотрудника и представителя руководящего состава УИИ Северо-Западного, Центрального, Дальневосточного и Южного федеральных округов. $70 \%$ опрошенных указали, что руководители предприятий отказывают в приеме на работу этой категории осужденных, поскольку не испытывают недостатка в рабочей силе и не заинтересованы в трудоустройстве лиц, которые в большинстве случаев не имеют соответствующих навыков и негативно относятся к работе [18, с. 57], а также в связи с тем, что на администрацию организаций в таком случае будут возложены определенные дополнительные обязанности, за неисполнение которых предусмотрен тот или иной вид ответственности.

Выход из сложившейся ситуации мы видим в проработке вопросов квотирования на предприятиях и в организациях рабочих мест для лиц, осужденных к исправительным работам. На региональном уровне соответствующие законодательные инициативы не были поддержаны. Основные причины такого положения кроются прежде всего в несовершенстве федерального и местного законодательства, что подтверждается и данными опроса: на это обстоятельство указали более 65 \% респондентов. Нередко это было связано с тем, что в соответствии с ч. 1 ст. 39 УИК РФ рабочие места для отбывания наказания в виде исправительных работ определяются по месту жительства осужденных органами местного самоуправления по согласованию с УИИ либо тем, что в соответствии с ч. 3 ст. 3 Федерального закона от 19.04.1991 № 1032-1 «О занятости населения в Российской Федерации» [9] осужденные по решению суда к исправительным работам не могут быть признаны безработными.

Статья 5 названного закона закрепляет, что государственная политика в области содействия занятости населения направлена на осуществление мероприятий, способствующих занятости граждан, испытывающих трудности в поиске работы, к которым относятся лица, освобожденные из учреждений, исполняющих наказание в виде лишения свободы, а также предполагает поощрение работодателей, сохраняющих действующие и создающих новые рабочие места прежде всего для граждан, испытывающих трудности в поиске работы. Мы предлагаем в круг последних включить осужденных, отбывающих наказание в виде исправительных работ, и тем самым приблизиться к решению проблем с их обязательным трудоустройством. Вопрос о мерах поощрения работодателей, например об установлении налоговых льгот, ФСИН России прорабатывается. Так, например, в 2018 г. территориальным органам ФСИН России было поручено инициировать рассмотрение в исполнительных органах государственной власти субъектов Российской Федерации вопроса о принятии дополнительных мер, предусматривающих оказание содействия в трудоустройстве лицам, осужденным к наказаниям и иным мерам уголовно-правового характера без изоляции от общества, предоставлении налоговых и иных льгот организациям и предприятиям, занимающимся трудоустройством лиц, осужденных к исправительным работам. Данное направление деятельности УИС в качестве приоритетного обозначено и в проекте документа по планированию дальнейшего развития уголовно-исполнительной системы - Концепции развития уголовно-исполнительной системы на период до 2030 г.

Мы разделяем мнение Р. Ф. Галлиевой о том, что давно назрела необходимость в законодательном порядке закрепить квотирование рабочих мест для осужденных к наказанию в виде исправительных работ, предусмотреть систему льгот в целях обеспечения заинтересованности работодателей в приеме на работу этой категории осужденных [2, с. 22], и результаты нашего исследования об этом свидетельствуют.

Так, в Забайкальском крае в целях стимулирования работодателей к организации рабочих мест для осужденных к исправительным работам, обеспечения социальной и трудовой адаптации осужденных, погашения ущерба, причиненного ими государству и потерпевшим гражданам, предусмотрено снижение на 4 \% налога на прибыль организациям, определенным органами местного самоуправления как места отбывания исправительных работ. Сумма снижения 
налога на прибыль организаций, трудоустроивших осужденных к отбыванию исправительных работ, за отчетный период не должна превышать 100 \% заработной платы, начисленной лицам, отбывающим исправительные работы [4].

Что же касается снижения ставки налога на прибыль организаций, предоставляющих рабочие места осужденным к исправительным работам, то в соответствии со ст. 284 Налогового кодекса Российской Федерации налоговая ставка налога на доходы организаций, подлежащего зачислению в бюджеты субъектов Российской Федерации, законами субъектов Российской Федерации может быть понижена для отдельных категорий налогоплательщиков, но не ниже 13,5 \%.

Анализ практики свидетельствует о том, что примерно 20 \% осужденных к исправительным работам в силу своего образа жизни испытывают серьезные трудности с предоставлением необходимых документов для заключения трудового договора с работодателем, часто у них отсутствуют документы, удостоверяющие личность. При обращении в структурные подразделения МВД России по вопросу получения паспорта указанным лицам отказывают в оформлении документов либо сроки оформления необоснованно затягиваются. Причинами этого служат чаще всего отсутствие у осужденного регистрации, получение документов не по месту регистрации [5, с. 105].

В связи с этим целесообразно издать методические рекомендации для сотрудников УИИ и осужденных, в которых следует указать, что, согласно приказу МВД России от 13.11.2017 № 851 «Об утверждении Административного регламента Министерства внутренних дел Российской Федерации по предоставлению государственной услуги по выдаче, замене паспортов гражданина Российской Федерации, удостоверяющих личность гражданина Российской Федерации на территории Российской Федерации» [13], определен исчерпывающий перечень оснований для отказа в выдаче паспорта, а именно: отсутствие у лица гражданства Российской Федерации; недостоверные сведения, указанные в заявлении о выдаче паспорта по установленной форме; отсутствие сведений об уплате государственной пошлины. При наличии всех необходимых документов паспорт оформляется и выдается в десятидневный срок со дня приема подразделениями всех необходимых документов в случае оформления паспорта по месту жительства, а также в связи с утратой паспорта, если утраченный паспорт ранее выдавался этим же подразделением; в тридцатидневный срок со дня приема подразделениями всех необходимых документов в случае оформления паспорта не по месту жительства или в связи с утратой паспорта, если утраченный паспорт ранее выдавался иным подразделением. Особо отметим, что при необходимости, например в случае трудоустройства осужденного к исправительным работам, в установленные законом сроки по желанию обратившегося может быть выдано временное удостоверение личности гражданина Российской Федерации на срок оформления паспорта. В этих же рекомендациях необходимо разъяснить осужденным и сотрудникам УИИ последствия отказа работодателя трудоустраивать осужденного к исправительным работам из-за отсутствия у него регистрации по месту проживания. Так, ст. 3 Трудового кодекса Российской Федерации установлено, что каждый имеет равные возможности для реализации своих трудовых прав. Никто не может быть ограничен в трудовых правах и свободах или получать какие-либо преимущества независимо от места жительства, других обстоятельств, не связанных с деловыми качествами работника. Кроме того, согласно ст. 64 ТК РФ, «какое бы то ни было прямое или косвенное ограничение прав или установление прямых или косвенных преимуществ при заключении трудового договора в зависимости от места жительства (в том числе наличия или отсутствия регистрации по месту жительства или пребывания), а также других обстоятельств, не связанных с деловыми качествами работников, не допускается». Следовательно, в случае если лицо считает, что оно подверглось дискриминации в сфере труда со стороны работодателя, то оно вправе обратиться с заявлением в суд о восстановлении нарушенных прав, возмещении материального вреда и компенсации морального ущерба. Сотрудники инспекции, в свою очередь, могут самостоятельно направить такую информацию в органы прокуратуры для принятия мер прокурорского реагирования. Таким образом, УИИ сможет решить вопрос о трудоустройстве осужденного и привлечении его к отбыванию исправительных работ, защитить права и законные интересы подучетного, а также окажет на него эффективное воспитательно-профилактическое 
воздействие. В противном случае осужденный продолжит вести паразитический образ жизни, у него будет отсутствовать официальный и постоянный источник дохода, что вполне вероятно вновь толкнет его на совершение преступления после постановки на учет в УИИ.

Практика показывает, что за 30 дней с момента получения приговора (ч. 2 ст. 39 УИК РФ) привлечь осужденного, не имеющего документов, необходимых для трудоустройства, к отбыванию наказания в виде исправительных работ нередко оказывается сложно. Вместе с тем УИИ не вправе принимать меры к осужденному к исправительным работам, который не предпринимает действий по получению или восстановлению соответствующих документов, поскольку в соответствии с законом отсутствие документов не является уважительной причиной неисполнения исправительных работ. Одним из возможных путей решения указанной проблемы мы считаем внесение изменений в п. 2 ст. 39 УИК РФ и изложение его в следующей редакции: «Осужденные к исправительным работам привлекаются уголовно-исполнительными инспекциями к отбыванию наказания не позднее 30 дней со дня поступления в уголовно-исполнительную инспекцию соответствующего распоряжения суда с копией приговора (определения, постановления). В случае отсутствия у осужденного необходимых для трудоустройства документов УИИ принимает меры, способствующие их получению, и направляет осужденного для отбывания наказания не позднее 50 дней со дня поступления в уголовно-исполнительную инспекцию соответствующего распоряжения суда с копией приговора (определения, постановления)».

Еще одним вариантом заключения трудового договора между работодателем и осужденным в случае отсутствия у последнего необходимых документов является привлечение к отбыванию исправительных работ только на основании приговора суда, вступившего в законную силу, и регистрации (постановки) на учет в УИИ (данную возможность поддержали 10 \% респондентов).

Говоря о проблемах трудоустройства осужденных при исполнении исследуемого наказания, нельзя не обратить внимание на содержание ч. 4 ст. 40 УИК РФ, где указывается, что осужденный не вправе отказаться от предложенной ему работы. Вместе с тем ч. 1 ст. 46 УИК РФ не предусмотрена правовая регламентация ответственности за отказ от предложенной работы, а также получения предписания УИИ с целью трудоустройства [17, с. 65].

Для устранения правовой неурегулированности нами предлагается ч. 3 ст. 46 УИК РФ изложить в следующей редакции: «Злостно уклоняющимся от отбывания исправительных работ признается осужденный, отказавшийся от предложенной ему работы, допустивший повторное нарушение порядка и условий отбывания наказания после объявления ему предупреждения в письменной форме за любое из указанных в части первой настоящей статьи нарушений, а также скрывшийся с места жительства осужденный, местонахождение которого неизвестно».

При таком подходе в случае отказа осужденного от предложенной работы он будет признан злостно уклоняющимся от отбывания исправительных работ и уголовноисполнительная инспекция направит в суд представление о замене исправительных работ другим видом наказания в соответствии с ч. 4 ст. 50 УК РФ.

Согласно постановлению Пленума Верховного Суда Российской Федерации от 22.12.2015 № 58 «О практике назначения судами Российской Федерации уголовного наказания» при решении вопроса о том, является ли злостным уклонение от отбывания исправительных работ, судам необходимо проверять обоснованность применения к осужденному предупреждений, указанных в ч. 2 ст. 46 УИК РФ, выяснять причины повторного нарушения порядка и условий отбывания наказания после объявления осужденному предупреждения в письменном виде, а также другие обстоятельства, свидетельствующие о нежелании осужденного работать (появление на работе в нетрезвом состоянии, прогулы, увольнение с работы, уклонение от обязанности сообщить об изменении места работы и места жительства и т. п.) [10].

Не менее остро стоит вопрос о материальной заинтересованности осужденного. Так, Федеральный закон от 02.10.2007 № 229-Ф3 «Об исполнительном производстве» [12] предусматривает возможность удержания с должника-гражданина не более 50 \% заработной платы и иных доходов. При этом ограничение размера удержания из заработной платы, а также других дохо- 
дов должника-гражданина, которое установлено ч. 2 ст. 99 указанного закона, не может применяться при взыскании алиментов на несовершеннолетних детей, возмещении вреда, причиненного здоровью, возмещении вреда в связи со смертью кормильца и возмещении ущерба, причиненного преступлением. В перечисленных нами случаях у осужденного к исправительным работам размер удержания из заработной платы и иных доходов как должника-гражданина может достигать 70 \%, и у него пропадает всякий интерес к заработку и работе. Статистика показывает, что к исправительным работам большое количество лиц осуждается по ст. 157, 158 и 161 УК РФ [15]. Данное осуждение чаще всего влечет за собой необходимость выплаты задолженности по алиментам или возмещение нанесенного ущерба. В рамках действующего механизма направления осужденных для отбывания исправительных работ предлагаемые места для отбывания наказания, как правило, низкооплачиваемые, в связи с чем далеко не каждый осужденный полностью отбывает исправительные работы.

Назначение осужденному исправительных работ предусматривает возложение на него обязанности трудиться по основному месту работы либо в местах, определяемых органами местного самоуправления по согласованию с уголовно-исполнительными инспекциями, но в районе места жительства осужденного (ч. 1 ст. 50 УК РФ).

Следовательно, отсутствие в некоторых, в основном удаленных населенных пунктах предприятий, учреждений и организаций делает практически неисполнимым судебное решение в случае назначения исправительных работ проживающему там осужденному и не позволяет тому реализовать свое право на труд ввиду неурегулированности законодателем возможности самостоятельного трудоустройства в другом муниципальном образовании.

Не можем не согласиться с мнением М. В. Арзамасцева о том, что существенным образом на исправление лица, совершившего преступление, влияет наличие у него постоянной работы [1, с. 6]. Обеспечить достойный уровень жизни себе и членам своей семьи, выполнить возложенные судом обязанности, связанные с материальными выплатами, данной категории лиц позволит именно обеспечение местом работы, развитие трудовых навыков. Также это ведет к предупреждению совершения новых преступлений.

На наш взгляд, в связи с ограниченной возможностью реализации осужденными к исправительным работам, не имеющими основного места работы, права на труд в районе места жительства целесообразно разрешить им по согласованию с осуществляющими надзор инспекциями самостоятельно трудоустраиваться за пределами района проживания. Поэтому необходимо внести изменения в ч. 1 ст. 50 УК РФ и изложить ее в следующей редакции: «Исправительные работы назначаются осужденному, имеющему основное место работы, а равно не имеющему его. Осужденный, имеющий основное место работы, отбывает исправительные работы по основному месту работы. Осужденный, не имеющий основного места работы, отбывает исправительные работы в местах, определяемых органами местного самоуправления по согласованию с уголовно-исполнительными инспекциями, но в районе места жительства осужденного либо в местах за пределами района места жительства осужденного в случае самостоятельного трудоустройства после вынесения приговора, но по согласованию с уголовно-исполнительной инспекцией».

Еще одним важным вопросом, требующим решения, является предоставление отпусков. Согласно ч. 6 ст. 40 УИК РФ в период отбывания исправительных работ ежегодный оплачиваемый отпуск продолжительностью 18 рабочих дней предоставляется администрацией организации, в которой работает осужденный, по согласованию с УИИ. Остальные виды отпусков, предусмотренные отечественным трудовым законодательством, предоставляются на общих основаниях. В действующих нормативных правовых актах отсутствуют нормы, регулирующие порядок учета времени отпуска, кроме ежегодного оплачиваемого отпуска, в сроке отбывания наказания и порядок производства удержаний в этот период.

К вопросу о привлечении к отбыванию наказания в виде исправительных работ некоторых категорий осужденных

Результаты проведенного нами исследования показывают, что весьма острой с точки зрения организационно-правового обеспечения деятельности УИИ остается проблема привлечения к исправительным работам осужденных, являющихся инвалидами. 75 \% 
опрошенных считают, что руководители предприятий и организаций не выполняют требования законодательства, в частности Федерального закона от 24.11.1995 № 181-Ф3 «О социальной защите инвалидов в Российской Федерации» [11], который обязывает их создавать или выделять рабочие места для трудоустройства инвалидов, в том числе осужденных к исправительным работам, в соответствии с квотой для приема на работу этой категории лиц.

Согласно закону федеральными органами государственной власти, органами государственной власти субъектов Российской Федерации инвалидам предоставляются гарантии трудовой занятости путем проведения следующих специальных мероприятий, способствующих повышению их конкурентоспособности на рынке труда:

- установление в организациях независимо от форм собственности гарантированного количества свободных рабочих мест для приема на работу инвалидов;

- стимулирование создания дополнительных рабочих мест (в том числе специальных) для трудоустройства инвалидов;

- квотирование рабочих мест по профессиям, наиболее подходящим для трудоустройства инвалидов;

- разработка программ реабилитации инвалидов и создание условий труда в соответствии с ними;

- развитие предпринимательской деятельности инвалидов;

- организация обучения, подготовки и переподготовки инвалидов по новым востребованным профессиям.

В соответствии с установленной квотой для приема на работу инвалидов работодатели обязаны:

- обеспечивать рабочие места для трудоустройства инвалидов;

- в соответствии с индивидуальной программой реабилитации инвалида создавать соответствующие условия труда.

Вместе с тем каждый третий эксперт считает, что руководство УИИ не проявляет инициативы в реализации требований указанного законодательного акта. 55 \% опрошенных сотрудников рассматривают в качестве сдерживающего фактора своевременного трудоустройства осужденных к исправительным работам, являющихся инвалидами, недобросовестность сотрудников УИИ в отношении своевременного уточнения перечня мест для отбывания наказания в виде исправительных работ с учетом наличия вакансий на предприятиях и в организациях. Почти каждый второй респондент уверен в том, что при организации исполнения исправительных работ этой категорией осужденных руководство территориальных органов ФСИН России не проявляет достаточной профессиональной настойчивости.

Органы государственной власти субъектов Российской Федерации в соответствии с законодательством имеют право содействия трудовой занятости инвалидов, в том числе посредством стимулирования создания специализированных рабочих мест для их трудоустройства, однако исследование показало, что в половине случаев на уровне регионов этот вопрос не решен.

Несмотря на снижение назначения судами исправительных работ несовершеннолетним [20, с. 4; 7, с. 120], проблема отбывания ими данного наказания стоит весьма остро. В частности, затруднения вызывает трудоустройство, поскольку, как правило, указанные лица не имеют специальности. Кроме того, трудовое законодательство содержит норму (ст. 63 ТК РФ), согласно которой трудовой договор заключается только с согласия одного из родителей и органов опеки и попечительства. В связи с этим нужно внести изменения в ст. 50 УК РФ, закрепив в ней условия привлечения к исправительным работам несовершеннолетних осужденных.

\section{Заключение}

Обобщая все вышесказанное, мы можем выделить следующие основные причины недостаточного привлечения к труду осужденных к исправительным работам:

- отсутствие эффективной предварительной работы, позволяющей создать условия для организации труда осужденных, как со стороны инспекции, так и со стороны территориального органа ФСИН России;

- низкий уровень взаимодействия инспекций с муниципальными органами различного уровня и государственными органами региона;

- отсутствие организационно-правового механизма стимулирования работодателей в сфере трудоустройства осужденных;

- непроработанность в органах государственной власти субъектов вопросов о необходимости внесения в региональное законодательство изменений для снижения налога на прибыль предприятий и организа- 
ций, которые предоставляют рабочие места осужденным к исправительным работам;

- отсутствие инициативы со стороны персонала инспекций в деле проработки вопросов гарантированного квотирования рабочих мест в учреждениях, где работают осужденные;

- осуществление воспитательно-профилактической деятельности инспекций по выявлению, предупреждению правонарушений, совершаемых осужденными, без достаточного кадрового и современного технического обеспечения;

- самоустранение администраций организаций, в которых работают осужденные к исправительным работам, от исполнения установленной законом обязанности по содействию уголовно-исполнительной инспекции в проведении воспитательной работы с осужденными (ст. 43 УИК РФ);

- загруженность сотрудников УИИ, нехватка персонала для эффективного решения указанных вопросов;

- недостаточное всестороннее изучение личности осужденного, склонного к совершению преступлений и иных правонарушений. Заметим, что неоднократно в монографических исследованиях предлагалось ввести практику досудебного доклада, в котором бы давалась всесторонняя характеристика лица, совершившего преступление, и определялись возможности применения $\mathrm{K}$ нему наказания или меры уголовно-правового характера, не связанных с изоляцией от общества, предполагаемые методы воздействия в ходе отбывания наказания.

\section{Выводы}

В науке уголовного и уголовно-исполнительного права давно ведется дискуссия по вопросу о сущности наказания в виде исправительных работ, прежде всего о соотношении в нем труда и кары: одни авторы усматривают проявление последней в обязательном участии осужденных в труде, другие - в трудовых, имущественных ограничениях, третьи - в трудовом воспитании, четвертые - в сочетании кары и воспитания. Стоит согласиться с исследователями, утверждающими, что сущность наказания в виде исправительных работ состоит в сочетании карательных и воспитательных элементов, что отражено в нормах уголовного и уголовно-исполнительного законодательства.

Результаты проведенного нами исследования свидетельствуют о том, что давно назрела необходимость внесения изменений в законодательные акты, касающиеся исполнения наказания в виде исправительных работ, для повышения эффективности соответствующей деятельности УИИ.

\section{СПИСОК ЛИТЕРАТУРЫ}

1. Арзамасцев, М. В. Проблемы определения места исполнения наказания в виде ограничения свободы / М. В. Арзамасцев // Уголовное право. - 2010. - № 4. - С. 4-7.

2. Галиева, Р. Ф. Правовое регулирование труда лиц, осужденных к исправительным работам / Р. Ф. Галиева // Уголовно-исполнительная система: право, экономика, управление. - 2011. - № 2. - С. 20-25.

3. Данные судебной статистики // Судебный департамент при Верховном Суде Российской Федерации : официальный сайт. - URL: http://www.cdep.ru/index.php?id=79\&item=4894 (дата обращения: 12.02.2021).

4. Заксобрание снизило налог на прибыль организаций, принимающих на работу осужденных // Информационное агентство «Чита.Pу» : официальный сайт. - URL: http://news.chita.ru/43780/ (дата обращения: 21.01.2021).

5. Князев, А. В. Опыт трудоустройства осужденных к исправительным работам в Ивановской области / А. В. Князев // Материалы II Всероссийского совещания руководителей аппаратов по руководству УИИ и заместителей начальников территориальных органов ФСИН России, курирующих их деятельность, по итогам работы службы исполнения наказаний, не связанных с лишением свободы, в 2007 году и задачах, стоящих перед службой на 2008-2009 годы (г. Уфа, 24-25 апреля 2008 г.). - Уфа : УФСИН России по Республике Башкортостан, 2008. - С. 105-110.

6. Косолапова, Д. В. К вопросу о совершенствовании правового регулирования деятельности уголовно-исполнительных инспекций по привлечению осужденных к отбыванию обязательных и исправительных работ / Д. В. Косолапова // Novalnfo - 2015. - № 34-4. - URL: https://novainfo.ru/article/3604 (дата обращения: 12.02.2021).

7. Лядов, Э. В. Вопросы совершенствования нормативного регулирования применения уголовного наказания в виде исправительных работ / Э.В. Лядов // Уголовно-исполнительная система на современном этапе и перспективы ее развития : сборник тезисов выступлений и докладов участников Международной научно-практической конференции (Рязань, 18-19 ноября 2020 г.). В 6 томах. Том 1. - Рязань : Академия ФСИН России, 2020. - С. 120-125. ISBN 978-5-7743-0969-6.

8. О внесении изменений в Уголовный кодекс Российской Федерации и отдельные законодательные акты Российской Федерации : Федеральный закон от 07.12.2011 № 420-Ф3 // Российская газета. - 2011. - 9 декабря; 2016. - 8 июля. 9. О занятости населения в Российской Федерации : закон Российской Федерации от 19.04.1991 № 1032-1 // Российская газета. - 1996. - 6 мая; 2020. - 11 декабря.

10. О практике назначения судами Российской Федерации уголовного наказания : постановление Пленума Верховного Суда Российской Федерации от 22.12.2015 № 58 // Российская газета. - 2015. - 29 декабря.

11. О социальной защите инвалидов в Российской Федерации : Федеральный закон от 24.11.1995 № 181 -Ф3 // Российская газета. - 1995. -2 декабря; 2021. - 11 января. 
12. Об исполнительном производстве : Федеральный закон от 02.10.2007 № 229-Ф3 // Российская газета. - 2007. 6 октября; 2021. - 11 января.

13. Об утверждении Административного регламента Министерства внутренних дел Российской Федерации по предоставлению государственной услуги по выдаче, замене паспортов гражданина Российской Федерации, удостоверяющих личность гражданина Российской Федерации на территории Российской Федерации : приказ МВД России от 13.11.2017 № 851 // Официальный интернет-портал правовой информации. - URL.: http://www.pravo.gov.ru (дата обращения: 12.02.2021).

14. Рязанов, В. В. О механизме исполнения альтернативных видов уголовных наказаний в России на примере обязательных и исправительных работ / В. В. Рязанов, Н. А. Кривошеев, О. А. Владимирова // Проблемы и перспективы развития уголовно-исполнительной системы России на современном этапе : материалы Всероссийской научной конференции адъюнктов, аспирантов, курсантов и студентов с международным участием (24 апреля 2020 г.). В 3 частях. Часть 3. - Самара : Самарский юридический институт ФСИН России, 2020. - С. 118-121. - ISBN 978-591612-286-2.

15. Сводные статистические сведения о состоянии судимости в России за 1 полугодие 2020 года № 10.1 «Отчет о числе привлеченных к уголовной ответственности и видах уголовного наказания» // Судебный департамент при Верховном Суде Российской Федерации : официальный сайт. - URL: http://www.cdep.ru/index.php?id=79\&item=5460 (дата обращения: 21.01.2021).

16. Тарабуев, Л. Н. К вопросу об исполнении наказания в виде исправительных работ / Л. Н. Тарабуев, Н. Н. Соловьева // Вузовская наука - региону : материалы XIV Всероссийской научной конференции. - Вологда : ВоГУ, 2016. C. $436-438$.

17. Тарабуев, Л. Н. Некоторые вопросы практики исполнения наказания в виде исправительных работ / Л. Н. Тарабуев, П. Н. Красоткин // Вестник института: преступление, наказание, исправление. - 2016. - № 1 (33). - С. $62-66$. 18. Тарабуев, Л. Н. Организация и правовые основы деятельности уголовно-исполнительных инспекций по исполнению наказания в виде исправительных работ : диссертация на соискание ученой степени кандидата юридических наук / Тарабуев Леонид Николаевич. - Ростов-на-Дону, 2018. - 253 с.

19. Устинов, А. А. Наказания в виде обязательных работ и исправительных работ: проблемы правовой регламентации / А. А. Устинов // IV Международный пенитенциарный форум «Преступление, наказание, исправление» (к 140-летию уголовно-исполнительной системы России и 85-летию Академии ФСИН России) : сборник тезисов выступлений и докладов участников (г. Рязань, 20-22 ноября 2019 г.). В 10 томах. Том 3. - Рязань : Академия ФСИН России, 2019. - С. 338-343. - ISBN 978-5-7743-0928-3.

20. Хисматуллина, Л. Проблемы назначения и исполнения исправительных работ в отношении несовершеннолетних / Л. Хисматуллина, В. Сафаров // Modern Science. - 2020. - № 5-2. - С. 226-230.

21. Чернышёва, Д. В. Организационные и правовые основы деятельности уголовно-исполнительных инспекций по привлечению осужденных к отбыванию обязательных и исправительных работ : диссертация на соискание ученой степени кандидата юридических наук / Чернышёва Диана Валентиновна. - Рязань, 2010. - 225 с.

\section{REFERENCES}

1. Arzamastsev M.V. Determining the place of execution of custodial sentences. Ugolovnoe pravo=Criminal Law, 2010, no. 4, pp. 4-7. (In Russ.).

2. Galieva R.F. Legal regulation of the work of persons sentenced to correctional labor. Ugolovno-ispolnitel'nayasistema: pravo, ekonomika, upravlenie=Penal System: Law, Economics, Management, 2011, no. 2, pp. 20-25. (In Russ.).

3. Judicial statistics data. Judicial Department at the Supreme Court of the Russian Federation: official website. Available at: http://www.cdep.ru/index.php?id=79\&item=4894 (accessed February 12, 2021). (In Russ.).

4. The Legislative Assembly has reduced the profit tax of organizations that employ convicts. Information Agency "Chita. Ru": official website. Available at: http://news.chita.ru/43780/ (accessed January 21, 2021). (In Russ.).

5. Knyazev A.V. Experience of employment of those sentenced to correctional labor in the Ivanovo Oblast. In: Materialy II Vserossiiskogosoveshchaniyarukovoditeleiapparatovporukovodstvu UII izamestiteleinachal'nikovterritorial'nykhor ganov FSIN Rossii, kuriruyushchikhikhdeyatel'nost', poitogamrabotysluzhbyispolneniyanakazanii, ne svyazannykh s lisheniemsvobody, v 2007 goduizadachakh, stoyashchikhpereds/uzhboina 2008-2009 gody (Ufa, 24-25 aprelya 2008 g.) [Proceedings of the 2 nd all-Russian meeting of heads of agencies for managing probation inspectorates and deputy heads of territorial bodies of the Federal Penitentiary Service of Russia in charge of their activities, on the results of the work of penal services not related incarceration in 2007 and the challenges that the service is facing, 2008-2009 (Ufa, April 24-25, 2008)]. Ufa: izdatel'stvo, 2008. Pp. 105-110. (In Russ.).

6. Kosolapova D.V. On the issue of improving the legal regulation of activity of probation inspectoratesrelated to engaging the prisoners sentenced to compulsory and correctional labor. Novalnfo, 2015, no. 34-4. (In Russ.).

7. Lyadov E.V. Improving the normative regulation of the application of criminal punishment in the form of correctional labor. In: Ugolovno-ispolnitel'nayasistemanasovremennometapeiperspektivyeerazvitiya: sborniktezisovvystupleniiidokladovuch astnikovMezhdunarodnoinauchno-prakticheskoikonferentsii (Ryazan', 18-19 noyabrya 2020 g.) [The penal system at the present stage and the prospects for its development: collection of abstracts of speeches and reports of participants of the International Scientific and Practical Conference (Ryazan, November 18-19, 2020)]. In 6 volumes. Volume 1. Ryazan: Akademiya FSIN Rossii, 2020. Pp. 120-125. (In Russ.).

8. On amendments to the Criminal Code of the Russian Federation and certain legislative acts of the Russian Federation: Federal Law 420-FZ of December 7, 2011. Rossiiskayagazeta=Russian Newspaper, 2011, December 9; 2016, July 8. (In Russ.).

9. On employment of the population in the Russian Federation: Law of the Russian Federation no. 1032-1of April 19, 1991. Rossiiskayagazeta=Russian Newspaper, 1996, May 6; 2020, December 11. (In Russ.).

10. On the practice of imposing criminal penalties by the courts of the Russian Federation: Resolution of the Plenum of the Supreme Court of the Russian Federation no. 58 of December 22, 2015. Rossiiskayagazeta=Russian Newspaper, 2015, December 29. (In Russ.).

11. On social protection of disabled persons in the Russian Federation: Federal Law 181-FZ of November $24,1995$. Rossiiskayagazeta=Russian Newspaper, 1995, December 2; 2021, January 11.

12. On enforcement proceedings: Federal Law 229-FZ of October 2, 2007. Rossiiskayagazeta=Russian Newspaper, 2007, October 6; 2021, January 11. (In Russ.). 
13. On approving the administrative regulations of the Ministry of Internal Affairs of the Russian Federation on the provision of state services for issuing and replacement of passports of the citizen of the Russian Federation, the identity of the citizen of the Russian Federation on the territory of the Russian Federation: order of the Ministry of Internal Affairs of Russia no. 851 of November 13, 2017. Official Internet portal of legal information. Available at: http://www.pravo.gov.ru/.

14. Ryazanov V.V., Krivosheev N.A., Vladimirova O.A. On the mechanism for execution of alternative types of criminal penalties in Russia on the example of compulsory and correctional work. In: Problemyiperspektivyrazvitiyaugolovno-ispolnitel'noisiste myRossiinasovremennometape: materialyVserossiiskoinauchnoikonferentsiiad"yunktov, aspirantov, kursantovistudentov s mezhdunarodnymuchastiem (24 aprelya $2020 \mathrm{~g}$.) [Problems and prospects of development of the penal system of Russia at the present stage: proceedings of the all-Russian scientific conference of adjuncts, postgraduates, cadets and students with international participation (April 24, 2020)]. In three parts. Part 3. Samara: Samarskiiyuridicheskiiinstitut FSIN Rossii, 2020. Pp. 118-121. (In Russ.).

15. Summary statistical data on the state of criminal records in Russia for the 1st half of 2020 no. 10.1 "A report on the number of persons brought to criminal responsibility and types of criminal punishment". Judicial Department at the Supreme Court of the Russian Federation: official website. Available at: http://www.cdep.ru/index.php?id=79\&item=5460 (accessed January 21, 2021). (In Russ.).

16. Tarabuev L.N., Solov'eva N.N. To the question of the execution of punishment in the form of correctional labor. In: Vuzovskayanauka -regionu: materialy XIV Vserossiiskoinauchnoikonferentsii [University science - to the region: proceedings of the 14thall-Russian scientific conference]. Vologda: VoGU, 2016. Pp. 436-438. (In Russ.).

17. Tarabuev L.N., Krasotkin P.N. Some questions of the practice of execution of punishment in the form of correctional labor. Vestnikinstituta: prestuplenie, nakazanie, ispravlenie=Institute Bulletin: Crime, Punishment, Correction, 2016, no. 1 (33), pp. 62-66. (In Russ.).

18. Tarabuev L.N. Organizatsiyaipravovyeosnovydeyatel'nostiugolovno-ispolnitel'nykhinspektsiipoispolneniyunakazan iya $v$ vide ispravitel'nykhrabot: dissertatsiyanasoiskanieuchenoistepenikandidatayuridicheskikhnauk [Organization and legal bases of the activities of probation inspectorates for the execution of punishment in the form of correctional labor: Candidate of Sciences (Law) dissertation]. Rostov-on-Don, 2018. 253 p.

19. Ustinov A.A. Punishments in the form of compulsory work and correctional work: problems of legal regulation. In: IV Mezhdunarodnyipenitentsiarnyi forum "Prestuplenie, nakazanie, ispravlenie" ( $k$ 140-letiyu ugolovnoispolnitel'noisistemyRossiii85-letiyu Akademii FSIN Rossii): sborniktezisovvystupleniiidokladovuchastnikov (g. Ryazan', 20-22 noyabrya 2019 g.) [4th international penitentiary forum "Crime, punishment, correction" (to the 140th anniversary of the penal system of Russia and the 85th anniversary of the Academy of the Federal Penitentiary Service of Russia): collection of abstracts of speeches and reports of participants (Ryazan, November 20-22, 2019).]. In 10 volumes. Volume 3. Ryazan: Akademiya FSIN Rossii, 2019. Pp. 338-343. (In Russ.).

20. Khismatullina L., Safarov V. Problems of the imposition and implementation of correctional work in relation to minors. Modern Science, 2020, no. 5-2, pp. 226-230. (In Russ.).

21. Chernysheva D.V. Organizatsionnyei pravovyeosnovydeyatel'nostiugolovno-ispolnitel'nykhinspektsiipoprivlecheniyu osuzhdennykh k otbyvaniyu obyazatel'nykh iispravitel'nykh rabot: dissertatsiya na soiskanie uchenoi stepeni kandidata yuridicheskikh nauk [Organizational and legal bases of activity of probation inspectorates to engage convictssentenced to compulsory and correctional work:Candidate of Sciences (Law) dissertation]. Ryazan, 2010. 225 p.

\section{СВЕДЕНИЯ ОБ АВТОРЕ / INFORMATION ABOUT THE AUTHOR}

ЛЕОНИД НИКОЛАЕВИЧ ТАРАБУЕВ - кандидат ЮридИческих наук, старший преподаватель кафедры боевой и тактико-специальной подготовки инженерно-экономического факультета Вологодского института права и экономики ФСИН России, г. Вологда, Российская Федерация. ORCID: https://orcid.org/0000-0003-3372-9810, e-mail: tarabuev@list.ru
LEONID N. TARABUEV - Candidate of Sciences (Law), senior lecturer at the Department of Combat and TacticalSpecial Training of the Faculty of Engineering and Economics, Vologda Institute of Law and Economics of FSIN Russia, Vologda, Russian Federation. ORCID: https:// orcid.org/0000-0003-3372-9810, e-mail: tarabuev@list.ru 